\title{
Seroprevalence of antibodies to Neospora caninum in dogs in the state of Alagoas, Brazil
}

\author{
Soroprevalência de anticorpos anti-Neospora caninum em cães no estado de Alagoas, Brasil
}

Maria Evódia de Sousa ${ }^{1}$; Wagnner José Nascimento Porto ${ }^{2}$; Pedro Paulo Feitosa de. Albuquerque ${ }^{1}$; Orestes Luiz de Souza Neto ${ }^{1}$; José Wilton Pinheiro Júnior ${ }^{3}$; Rinaldo Aparecido Mota ${ }^{1 *}$

\begin{abstract}
${ }^{1}$ Laboratório de Bacterioses, Departamento de Medicina Veterinária, Universidade Federal Rural de Pernambuco - UFRPE, Recife, PE, Brasil

${ }^{2}$ Departamento de Medicina Veterinária, Universidade Federal de Alagoas - UFAL, Viçosa, Viçosa, AL, Brasil

${ }^{3}$ Departamento de Medicina Veterinária, Unidade Acadêmica de Garanhuns - UAG, Garanhuns, PE, Brasil
\end{abstract}

Received July 27, 2011

Accepted November 17, 2011

\begin{abstract}
This study investigated occurrences of antibodies to anti-Neospora caninum in dogs in the state of Alagoas, Brazil, and the risk factors associated with the infection. To investigate antibodies against $N$. caninum, an indirect immunofluorescence antibody test (IFAT) was used. To identify risk factors associated with infection by $N$. caninum, univariate analyses on variables of interest were conducted. The study analyzed 237 samples from dogs of both sexes and different breeds and ages, both from rural and from urban areas. Ten animals (4.2\%) were seropositive: five (4.8\%) from rural areas and five (3.8\%) from urban areas. Regarding sex, five (4.0\%) were male and five (4.5\%) were female. In relation to breed, four animals of undefined breed and six of defined breed were positive. The ages of the seropositive animals ranged from two months to eleven years. Results show there are no significant associations between seropositivity and the variables analyzed. Results indicate neosporosis must be included in differential diagnosis of dog neurological disorders.
\end{abstract}

Keywords: Neosporosis, dogs, epidemiology, diagnosis, IFAT.

\section{Resumo}

Investigou-se a ocorrência de anticorpos anti-Neospora caninum em cáes no Estado de Alagoas, Brasil e os fatores de risco associados à infecçáo. Para a pesquisa de anticorpos contra $N$. caninum empregou-se a Reação de Imunofluorescênica Indireta (RIFI). Para identificar os fatores de risco associados à infecção pelo $N$. caninum foi realizada análise univariada das variáveis de interesse. Foram analisadas 237 amostras de cáes de ambos os sexos, diferentes raças e idades e procedentes de áreas urbanas e rurais. Obteve-se 10 (4,2\%) animais soropositivos, sendo cinco (4,8\%) de áreas rurais e cinco $(3,8 \%)$ de áreas urbanas. Com relação ao sexo, cinco $(4,0 \%)$ eram machos e cinco $(4,5 \%)$ fêmeas. Quanto às raças foram positivos quatro animais de raças indefinidas e seis de raças definidas. As idades dos animais soropositivos variaram de dois meses a 11 anos. Os resultados da análise estatística revelaram não haver associação significativa entre a soropositividade e as variáveis analisadas. Os resultados indicam a necessidade de incluir a neosporose no diagnóstico diferencial das desordens neurológicas caninas.

Palavras-chave: Neosporose, cães, epidemiologia, diagnóstico, RIFI.

Neospora caninum is an obligate intracellular parasite (COX, 1991; DUBEY, 2003) that causes neosporosis, a neuromuscular disease usually characterized by an ascendant parasite that can cause a great variety of clinical signs (BARBER, 1998; DUBEY et al., 1988). This agent has a large economic impact, since it is one of

\footnotetext{
*Corresponding author: Rinaldo Aparecido Mota

Laboratório de Bacterioses, Departamento de Medicina Veterinária,

Universidade Federal Rural de Pernambuco - UFRPE,

Rua Dom Manoel de Medeiros, s/n, Dois Irmáos, CEP 52171-900,

Recife, PE, Brasil

e-mail: rinaldo.mota@hotmail.com
}

the most important causes of abortions in cattle and neurological signs in dogs. The most important fact is that dogs serve as the definite hosts of the parasite and disseminate the agent to other animals (MCALLISTER et al., 1998; DUBEY et al., 2007).

The parasite can attack various domestic and wild animals (DUBEY, 2003), but it consistently causes sickness in dogs and in cattle (BUXTON et al., 2002).

Different risk factors may be involved in the epidemiology of infection by $N$. caninum. Among them are the origin and age of the dogs, as well as the way in which the bodies of dead animals on farms are disposed of (CUNHA FILHO et al., 2008). 
In view of the absence of epidemiological information about infection by this parasite in dogs in the state of Alagoas, the objective of this study was to investigate occurrences of anti- $N$. caninum antibodies in dogs, in the state of Alagoas, Brazil, and to assess the risk factors associated with infection in this species.

This investigation was carried out in different neighborhoods in the capital of the state of Alagoas (Maceió) and on farms in all regions of the state (eastern region, Agreste plateau region and Alagoan Semi-arid Sertão region), on which cattle breeding is the main activity.

The study included 237 randomly chosen dogs of different breeds and ages, of which 125 were male and 112 were female, without any clinical signs suggestive of the disease. The breeds were stratified into two major groups (defined and undefined breeds), to facilitate the statistical analysis. Within these two groups, the following categories were considered: domiciled dogs (rural domiciliation, i.e. dogs that were restricted to the property or farm; urban domiciliation, i.e. dogs that had a fixed home and never went out onto the streets without a guide); semi-domiciled (rural semi-domiciliation, i.e. dogs that were restricted to the property or farm but were sometimes released; urban semi-domiciliation, i.e. dogs that had a fixed home, but had free access to the streets); and free (rural free, i.e. dogs that lived free on the property or farm; urban free, i.e. street dogs without a home). Free animals were animals that frequented the farm properties and urban domiciles, but did not have owners. Blood collection from these free animals was carried out when we were able to catch them, and they were released after collection. One hundred and four dogs were from rural areas and 133 were from urban areas. One hundred and twenty had a home, 86 were semi-domiciled and 31 were free.

The blood samples were collected by means of cephalic vein puncture using sterile syringes and needles $(30 \times 8 \mathrm{~mm})$, after antisepsis of the site using $70 \%$ alcohol. The blood was placed in assay tubes without anticoagulant and these tubes were kept packed in styrofoam at room temperature for approximately 5 to 6 hours. They were then taken to the laboratory to be centrifuged, and the serum obtained was stored in Eppendorf tubes and refrigerated at $-20^{\circ} \mathrm{C}$ until the time of the serological test. At the time of the blood collection, a questionnaire was applied to the animal's owners, always by the same investigator, consisting of objective questions about the animal and its handling. The variables analyzed were the dogs' age, breed, food, sex, origin (rural or urban) and type of domiciliation (domiciled, semi-domiciled and free).

To detect IgG anti- $N$. caninum antibodies, the indirect immunofluorescence antibody test (IFAT) was used, following the method recommended by Dubey (1988), with a cutoff point of 1:50. Serum samples that were positive at this titer were serially diluted by means of twofold dilution until reaching the maximum reagent titration. $N$. caninum tachyzoites of the NC1 strain, maintained in a culture of VERO cells (FERNANDES et al., 2004), were used as antigens. Previously known positive and negative serum controls were used. Anti-canine IgG antibodies conjugated with fluorescein isothiocyanate (Sigma Chemical) were also used. Only samples that demonstrated total peripheral fluorescence from the tachyzoites were considered positive (DUBEY, 1988).

The data were organized in electronic table format (Microsoft Excel). Each of the potential risk factors included in the questionnaire was individually compared, using contingency tables, with a categorical variable representing the seropositivity of the animals (positive or negative). The significance level used was 5\%. The significance of each of the associations was determined using the chi-square test or Fisher's exact test (THRUSFIELD, 2004), using the Epi Info software, version 6.0 (DEAN et al., 1994).

Out of the 237 samples analyzed, 10 (4.2\%) were positive and 227 (95.8\%) were negative. The frequency of positive samples was lower than in the majority of the studies consulted (6.7\% for MINEO et al., 2001, in Uberlândia, MG; and 45\% for BENETTI et al., 2008, in Cuiabá, MT). Despite the small number of positive animals, these results are important from an epidemiological viewpoint, since this is the first report of this infection in dogs in the state of Alagoas.

With regard to sex, five males (4.0\%) and five females (4.5\%) were positive, and there was no statistically significant difference between the sexes, as was also described in the studies carried out by Oliveira et al. (2004), Jesus et al. (2006), Romanelli et al. (2007), Benetti et al. (2008) and Moraes et al. (2008). Moreover, when this variable was subjected to univariate analysis $(P=0.859)$, there was no association with occurrences of anti- $N$. caninum antibodies, thus demonstrating that in this region, males and females can be equally stricken and are subject to the same risks of infection (BOAVENTURA et al., 2007; CUNHA FILHO et al., 2008).

In relation to the type of environment, five dogs ( $4.8 \%)$ from rural areas were positive (four lived in restricted areas, but were released at some point during the day, and one lived completely free on the farm property), as well as five (3.8\%) from urban areas (three domiciled and two semi-domiciled). Studies carried out on this topic have indicated that there is higher prevalence among dogs in rural areas and stray dogs than among dogs in urban areas (BENETTI et al., 2008).

There was no statistically significant difference $(P=0.751)$ among animals in rural areas and animals in urban areas in this study (Table 1). In rural areas there is greater access to infection sources, because in these areas, the animals have the chance to consume material from dead animals left in the fields, as well as aborted cattle fetuses and placental remains (MAGALHÁES et al., 2009).

According to Cunha Filho et al. (2008), the risk of infection is 2.2 times higher on farm properties where dead bodies of animals and fetuses are not removed from the fields, than on farm properties where dead bodies are adequately removed.

The presence of positive dogs on rural properties is an important finding from an epidemiological viewpoint, since it represents a potential risk factor for infection of cattle and other productive species (SCHARES et al., 2004). According to Corbellini et al. (2006), for each additional dog on the property the likelihood that a cow would be seropositive increases by a factor of 1.13.

The ages of the seropositive animals ranged from 2 months to 11 years, and only two animals were less than one year old. The results from this study did not reveal any statistically significant association between seropositivity and age, but dogs between one and three years of age presented a 1.47 times higher chance of becoming infected, in relation to the other categories (Table 1). Other studies have revealed similar results, i.e. showing that 
Table 1. Univariate analysis on risk factors with and without associations with presence of antibodies anti-N. caninum among dogs in the state of Alagoas, Brazil.

\begin{tabular}{|c|c|c|c|c|c|c|c|}
\hline \multirow{3}{*}{ Variable } & \multicolumn{4}{|c|}{ Indirect immunofluorescence antibody test } & \multirow{2}{*}{\multicolumn{2}{|c|}{ Total }} & \multirow{3}{*}{$\begin{array}{c}\text { Value p } \\
\text { OR }(95 \% \text { CI })\end{array}$} \\
\hline & \multicolumn{2}{|c|}{ Positive } & \multicolumn{2}{|c|}{ Negative } & & & \\
\hline & AF & RF (\%) & AF & RF (\%) & AF & RF (\%) & \\
\hline \multicolumn{8}{|l|}{ Sex } \\
\hline Male & 5 & 4.0 & 120 & 96.0 & 125 & 100.0 & 0.859 \\
\hline Female & 5 & 4.5 & 107 & 95.5 & 112 & 100.0 & $0.89(0.20-3.99)$ \\
\hline Breed & - & - & - & - & - & - & - \\
\hline \multicolumn{8}{|l|}{ Age } \\
\hline$<1$ year & 2 & 5.1 & 37 & 94.9 & 39 & 100.0 & 0.879 \\
\hline 1 to 3 years & 4 & 3.5 & 109 & 96.5 & 113 & 100.0 & $1.47(0.13-19.79)$ \\
\hline$>3$ years & 4 & 4.7 & 81 & 95.3 & 85 & 100.0 & $0.74(0.13-4.12)$ \\
\hline \multicolumn{8}{|l|}{ Origin } \\
\hline Domiciled & 3 & 2.5 & 117 & 97.5 & 120 & 100.0 & 0.276 \\
\hline Semi-domiciled & 6 & 7.0 & 80 & 93.0 & 86 & 100.0 & $0.34(0.05-1.66)$ \\
\hline Free & 1 & 3.2 & 30 & 96.8 & 31 & 100.0 & $2.25(0.25-106.89)$ \\
\hline \multicolumn{8}{|l|}{ Food } \\
\hline Without access to abortions & 8 & 4.3 & 180 & 95.7 & 188 & 100.0 & 1.000 \\
\hline With access to abortions & 2 & 4.1 & 47 & 95.9 & 49 & 100.0 & $1.04(0.20-10.42)$ \\
\hline
\end{tabular}

Base = 237 dogs. Legend: OR - odds ratio; CI - confidence interval; AF - absolute frequency; RF - relative frequency.

seropositivity for $N$. caninum was higher in dogs that were over one year of age (FERNANDES et al., 2004; MORAES et al., 2008).

In relation to breed, four dogs of mixed breed, three Poodles, one German Shepherd, one Rottweiler and one German White were positive. According to the statistical analysis, there was also no significant difference $(\mathrm{P}=0.749)$ between defined and undefined animal breeds, even when the defined breed presented 1.46 times more chances of becoming infected than the undefined breed. These results corroborate the findings of Romanelli et al. (2007) and Jesus et al. (2006), who also did not find any statistically significant difference in relation to breed among the animals studied, thus indicating that all breeds are equally susceptible to the agent.

With regard to food, the present study did not indicate statistical significance among dogs with access to aborted fetuses and dogs whose food was based on commercial feedstuff. A similar result was obtained by Benetti et al. (2008), in a study on occurrences of anti-Neospora caninum antibodies in dogs in the state of Mato Grosso.

This is the first report on occurrences of anti-Neospora caninum antibodies in dogs in the state of Alagoas, and it will contribute towards the knowledge of neosporosis epidemiology, through supplying data for controlling the infection in this region. The results point towards the need to including canine neosporosis in the differential diagnosis of neurological disorders of dogs in the regions studied, along with the need for greater vigilance in relation to the influence of dogs on reproductive losses among cattle in the rural areas of the regions studied.

\section{References}

Barber JS. Neosporosis canina. Waltham Int Focus 1998; 8(1): 25-29.

Benetti AH, Toniollo GH, Santos TR, Gennari SM, Costa AJ, Dias RA. Ocorrência de anticorpos anti-Neospora caninum em cães no município de Cuiabá, Mato Grosso. Cienc Anim Bras 2008; 9(1): 177-180.

Boaventura CM, Oliveira VSF, Melo DPG, Borges LMF, Silva AC. Prevalência de Neospora caninum em cães de Goiânia. Rev Patol Trop 2007; 37(1): 15-22.

Buxton D, Mcallister MM, Dubey JP. The comparative pathogenesis of neosporosis. Trends Parasitol 2002; 18(12): 546-552. PMid:12482540. http://dx.doi.org/10.1016/S1471-4922(02)02414-5

Corbellini LG, Smith DR, Pescador CA, Schimitz M, Correa A, Steffen $\mathrm{Dj}$, et al. Herd-level risk factors for Neospora caninum seroprevalence in dairy farms in southern Brazil. Prev Vet Med 2006; 74(2-3): 130-141. PMid:16343669.

Cox FEG. Systematics of parasitic protozoa. In: Krier JP. Parasitic Protozoa. 2nd ed. Local: Academic Press; 1991. v. 1, p. 55-67.

Cunha Filho NA, Lucas AS, Pappen FG, Ragozo AMA, Gennari SM, Lucia Junior TL, et al. Fatores de risco e prevalência de anticorpos anti-Neospora caninum em cães urbanos e rurais do Rio Grande do Sul, Brasil. Rev Bras Parasitol Vet 2008; 17(1): 301-306.

Dean AG, Dean JA, Coulombier D. Epi Info. version 6.01: A Word Processing, Database and Statistics Program for epidemiology on Microcomputers. Atlanta: Centers for Disease Control and Prevention; 1994. 
Dubey JP. Neosporosis - the first decate of research. Int $J$ Parasitol 1988; 29(10): 1485-1488. http://dx.doi.org/10.1016/ S0020-7519(99)00134-4

Dubey JP. Review of Neospora caninum and neosporosis in animals. Korean J Parasitol 2003; 41(1): 1-16. PMid:12666725. http://dx.doi. org/10.3347/kjp.2003.41.1.1

Dubey JP, Carpenter JL, Speer CA, Topper MJ, Uggla A. A newly recognised fatal protozoan disease of dogs. J Am Vet Med Assoc 1988; 192(9): 1269-1285. PMid: 3391851.

Dubey JP, Schares G, Ortega-Mora LM. Epidemiology and control of neosporosis and Neospora caninum. Clin Microbiol Rev 2007; 20: 323-367. PMid:17428888. http://dx.doi.org/10.1128/CMR.00031-06

Fernandes BCTM, Gennari SM, Souza SLP, Carvalho JM, Oliveira WG, Cury MC. Prevalence of anti-Neospora caninum antibodies in dogs from urban, periurban and rural áreas of the city of Uberlândia, Minas Gerais, Brasil. Vet Parasitol 2004; 123(1-2): 33-40. http://dx.doi.org/10.1016/j. vetpar.2004.05.016

Jesus EEV, Santos POM, Barbosa MVF, Pinheiro AM, Gondim LFP, Guimarães JE, et al. Frequencia de anticorpos anti-Neospora caninum em cães nos municípios de Salvador e Lauro de Freitas, Estado da Bahia - Brasil. Braz J Vet Res Anim Sci 2006; 43(1): 5-10.

Magalhães VCS, Sicupira PML, Gondim LFP, Munhoz AD. Frequencia de anticorpos contra Neospora caninum em cães do município de Ilhéus, Bahia. Cienc Anim Bras 2009; 10(1): 306-311.
Mcallister MM, Dubey JP, Lindsay DS, Jolley WR, Wills RA, Mcguire AM. Dogs are definitive hosts of Neospora caninum. Int J Parasitol 1998; 28: 1473-1478. PMid:9770635.

Mineo TWP, Silva DAO, Costa GHN, Von Ancken ACB, Kasper LH, Souza MA et al. Detection of IgG antibodies to Neospora caninum and Toxoplasma gondii in dogs examined in a veterinary hospital from Brazil. Vet Parasitol 2001; 98: 239-245. http://dx.doi.org/10.1016/ S0304-4017(01)00441-1

Moraes CCG, Megid J, Pituco EM, Okuda LH, Del Fava C, Stefano E, et al. Ocorrência de anticorpos anti-Neospora caninum em cães da Microrregião da Serra de Botucatu, Estado de São Paulo, Brasil. Rev Bras Parasitol Vet 2008; 17(1): 1-6. http://dx.doi.org/10.1590/ S1984-29612008000100001

Oliveira JM, Matos MFC, Oshiro LM, Andreotti R. Prevalence of anti- Neospora caninum antibodies in dogs in the urban área of Campo Grande, MS, Brazil. Rev Bras Parasitol Vet 2004; 13(4): 155-158. http:// dx.doi.org/10.1590/S1984-29612007000300004

Romanelli PR, Freire RL, Vidotto O, Marana ERM, Ogawa L, De Paula VSO, et al. Prevalence of Neospora caninum and Toxoplasma gondii in sheep and dogs from Guarapuava farms, Paraná State, Brazil. Res Vet Sci 2007; 82: 202-207. http://dx.doi.org/10.1016/j.rvsc.2006.04.001

Schares G, Barwald A, Staubachi C, Ziller M, Kloss D, Schroder R, et al. Potential risk factors for bovine Neospora caninum infection in Germany are not under the control of the farms. Parasitology 2004; 129: 301-309. PMid:15471005.

Thrusfield MV. Epidemiologia Veterinária. 2. ed. São Paulo: Roca, 2004. 556 p. 